\title{
Analisis Faktor-Faktor yang Memengaruhi Minat Kunjungan Wisatawan Berdasarkan Komponen Destinasi Wisata di Kawasan Kuliner, Pasar Lama Tangerang
}

\author{
Antonius Rizki Krisnadi ${ }^{\mathrm{a} 1,{ }^{*}}$, Dessy Natalia $^{\mathrm{b} 2}$ \\ ${ }^{a}$ Prodi Hospitality dan Pariwisata - Universitas Bunda Mulia Jakarta \\ ${ }^{\mathrm{b}}$ Prodi Hospitality dan Pariwisata - Universitas Bunda Mulia Jakarta \\ ${ }^{1}$ akrisnadi@bundamulia.ac.id, ${ }^{2}$ dnatalia@bundamulia.ac.id \\ *corresponding author
}

ARTICLE INFO

Article history

Received

Revised

Accepted

Keywords

Attraction

Visiting Interest

TouristsDestination

Culinary Tourism

Tangerang Old Market

\begin{abstract}
Tourism in the city of Tangerang continues to experience an increase in the number of tourist visits. Based on data obtained from the Tangerang City Statistics Center, the number of tourist visits continues to increase, including an increase of 46.79\% from 2017 to 2018. One of the most visited tourist destinations, culinary attractions in the Old Market, Tangerang. Culinary is a tourist attraction that is no longer a support in tourism, but instead becomes the main destination of tourists to carry out a tourism activity (Kristiana, Suryadi and Sunarya, 2018). Every tourist who will visit a tourist destination definitely needs a variety of services and facilities to reach that destination. This study aims to determine whether each dimension of attraction, accessibility, amenities, and ancillary services in the tourist destination component significantly influences the interest of tourists visiting the Tangerang Old Market Culinary Area. The theory used in this study is according to Cooper et al. in Anggela, Karini, \& Wijaya (2017), which states that the components of a tourist destination have four dimensions, namely attraction, accessibilities, amenities, and ancillary services. Based on the results of the t test it is known that the dimension of attraction has a significant influence on the interest of tourist visits in the Tangerang Old Market Culinary Area, while the other three dimensions have no significant effect. Based on the results of the F Test simultaneously it is known that the component of the tourist destination has a significant influence on the interest of tourist visits in the Tangerang Old Market Culinary Area. Based on the Determination Coefficient Test results obtained by $38.6 \%$. Suggestions from this research are so that the Culinary Area can be made more attractive and has special characteristics, adding detailed information about access to the location, completing facilities according to the needs of consumers and keeping it clean and completing additional services such as security posts and also Money Changer services.
\end{abstract}

\section{Pendahuluan}

\subsection{Latar Belakang}

Pariwisata di Indonesia menimbulkan berbagai dampak positif atau yang dikenal dengan istilah "multiplier effect". Selain meningkatkan devisa negara, pariwisata juga membantu menciptakan lapangan pekerjaan, meningkatkan kesejahteraan masyarakat, dan juga meningkatkan berbagai industri lain, seperti industri kuliner, transportasi, penginapan dan industri terkait lainnya.

Berbagai dampak positif yang ditimbulkan oleh sektor pariwisata menyebabkan pemerintah, baik Pemerintah Pusat maupun Pemerintah Daerah, terus berupaya mengembangkan pariwisata di daerahnya. Salah satunya, yaitu Pemerintah Daerah Kota Tangerang. 
Pariwisata di Kota Tangerang terus mengalami peningkatan. Hal ini ditandai dengan meningkatnya jumlah kunjungan wisatawan, yakni baik wisatawan nusantara maupun wisatawan mancanegara yang datang ke Kota Tangerang dari tahun ke tahun, seperti yang dapat dilihat pada tabel berikut ini:

\section{Tabel 1.1}

Jumlah Wisatawan Nusantara Dan Wisatawan Mancanegara Di Kota Tangerang (Orang)

\begin{tabular}{cccc}
\hline Tahun & Wisatawan Nusantara & Wisatawan Mancanegara & Jumlah \\
\hline 2016 & 469.173 & 85.126 & 554.299 \\
\hline 2017 & 793.502 & 295.245 & 1.088 .747 \\
\hline 2018 & 1.360 .154 & 237.996 & 1.598 .150 \\
\hline
\end{tabular}

Sumber: Kota Tangerang Dalam Angka, 2019

Menurut data dari Badan Pusat Statistik Kota Tangerang, sampai tahun 2018 terdapat 57 destinasi wisata di Kota Tangerang. Salah satu destinasi wisata yang ramai dikunjungi yaitu objek wisata kuliner Pasar Lama Tangerang.

Kawasan Kuliner Pasar Lama Tangerang terletak di Jalan Kisamaun, Sukasari, Kecamatan Tangerang, Kota Tangerang, Provinsi Banten. Wisata kuliner ini biasanya ramai dikunjungi mulai pukul 17.00 WIB sampai pukul 22.00 WIB. Di sana, wisatawan dapat menemukan berbagai macam street food yang dijual dengan harga yang terjangkau. Oleh karena itu, Kawasan Kuliner Pasar Lama Tangerang menjadi tempat favorit para pencinta wisata kuliner dan ramai dikunjungi, khususnya saat akhir pekan.

Kuliner merupakan suatu daya tarik wisata yang bukan lagi sebagai penunjang dalam pariwisata, namun merupakan tujuan utama bagi wisatawan untuk melakukan suatu kegiatan wisata (Kristiana, Suryadi dan Sunarya, 2018). Menurut Long dalam Muliani (2019), wisata kuliner atau yang disebut juga dengan culinary tourism merupakan kegiatan pariwisata yang memiliki tujuan untuk eksplorasi cita rasa makanan dan kebiasaan makan di suatu daerah tertentu. Setiap wisatawan yang melakukan perjalanan ke suatu destinasi wisata pasti memerlukan berbagai pelayanan dan kemudahan untuk mencapai destinasi tersebut. Beberapa pelayanan yang menjadi kebutuhan wisatawan adalah restoran, hotel dan akomodasi serta moda transportasi untuk pergi dari satu tempat tujuan wisata menuju ke tempat tujuan wisata lainnya. Menurut Cooper dkk. dalam Anggela, Karini, \& Wijaya (2017), terdapat empat komponen yang harus dimiliki suatu destinasi wisata, yaitu attraction, amenities, accessibilities, dan ancillary service.

\subsection{Komponen Destinasi Wisata}

Menurut Cooper dkk. dalam Anggela, Karini, \& Wijaya (2017), terdapat empat komponen yang harus dimiliki dalam pengembangan suatu destinasi wisata, yaitu:

1. Atraksi (Attraction), yakni daya tarik yang dimiliki oleh suatu daerah. Terdapat tiga jenis atraksi yang menjadi faktor penarik kedatangan wisatawan, yaitu potensi alam yang dimiliki, wisata budaya serta wisata buatan.

2. Aksesibilitas (Accessibilities), yakni kemudahan pergerakan atau perpindahan bagi wisatawan, seperti kemudahan akses untuk menuju objek wisata dan kemudahan untuk menemukan 
3. Amenitas (Amenities), yakni fasilitas-fasilitas yang dibutuhkan oleh wisatawan yang dapat menunjang kegiatan wisata di suatu destinasi pariwisata, seperti ketersediaan fasilitas umum, fasilitas penginapan, tempat yang menjual makanan dan minuman serta fasilitas lainnya.

4. Layanan Tambahan (Ancillary Services), yakni layanan yang menunjang kegiatan pariwisata.

\subsection{Minat Kunjungan}

Philip Kotler, John Bowen, dan James Makens dalam Putra \& Pangestuti (2018), menyatakan bahwa minat berkunjung wisatawan untuk berkunjung ke suatu destinasi wisata dapat disetarakan dengan minat pembelian konsumen karena keduanya dapat diukur dengan indikator yang sama. Menurut Ferdinand dalam Wilopo \& Pangestuti (2017), minat beli dapat diukur dengan indikatorindikator berikut ini:

- Minat transaksional, merupakan kecenderungan untuk membeli suatu produk.

- Minat referensial, merupakan kecenderungan untuk mereferensikan produk kepada orang lain.

- Minat preferensial, merupakan minat seseorang yang memiliki preferensi utama pada suatu produk dan akan dapat terganti jika terjadi sesuatu dengan produk preferensinya.

- Minat eksploratif, merupakan minat seseorang untuk selalu mencari informasi mengenai produk yang diminatinya dan informasi pendukung mengenai produk tersebut.

\subsection{Wisatawan}

Berdasarkan hasil Konferensi PBB (Perserikatan Bangsa-Bangsa) tentang Perjalanan dan Kepariwisataan tahun 1963, menjelaskan bahwa pengunjung (visitor) dapat dibagi menjadi dua jenis, yaitu wisatawan (tourist) dan pelancong (excurtionist), dengan penjelasan sebagai berikut:

- Wisatawan (tourist)

- Merupakan mereka yang berkunjung minimal 24 jam di negara yang dikunjungi.

- Pelancong (excurtionist)

- Merupakan mereka yang berkunjung sementara dan tinggal kurang dari 24 jam pada destinasi tujuan dan tidak bermalam.

WTO (World Tourism Organization) dalam Nengsih dan Ariska (2020), membagi wisatawan ke dalam tiga bagian, yaitu:

- Pengunjung

Merupakan setiap orang yang melakukan perjalanan ke negara lain di luar tempat kediamannya, dengan alasan melakukan pekerjaan yang diberikan oleh negara yang dikunjunginya.

- Wisatawan

Merupakan setiap orang yang bertempat tinggal di suatu negara tanpa memandang kewarganegaraannya, melakukan perjalanan ke suatu tempat pada negara yang sama selama lebih dari 24 jam dengan tujuan diantaranya yaitu:

- Melakukan kegiatan rekreasi, liburan kesehatan, pendidikan, keagamaan dan olahraga.

- Bisnis atau mengunjungi keluarga.

- Darmawisata atau excursionist

Merupakan setiap orang yang berkunjung sementara dan menetap kurang dari 24 jam di negara yang dikunjunginya 


\section{Metode Penelitian}

Penelitian ini merupakan penelitian kuantitatif, di mana Komponen Destinasi Wisata merupakan variable X dan Minat kunjungan sebagai variable Y. Menurut Arikunto (2013), subjek penelitian, yaitu sesuatu yang kedudukannya sangat penting dalam penelitian karena pada subjek penelitian terdapat data tentang variabel yang diteliti dan diamati. Subjek penelitian ini dapat berupa benda, hal atau orang. Pada penelitian ini, subjek penelitian yaitu wisatawan yang berkunjung ke Kawasan Kuliner Pasar Lama Tangerang.

Dalam penelitian ini, objek penelitian adalah Analisis Faktor-Faktor Yang Mempengaruhi Minat Kunjungan Wisatawan Berdasarkan Komponen Destinasi Wisata di Kawasan Kuliner Pasar Lama Tangerang. Populasi merupakan sekumpulan individu dengan karakteristik khas yang menjadi perhatian dalam suatu penelitian (pengamatan) dalam ruang lingkup yang diteliti. Populasi dalam penelitian ini adalah seluruh wisatawan yang berkunjung ke Kawasan Kuliner Pasar Lama Tangerang. Penentuan jumlah sampel dilakukan berdasarkan teori Hair et al., (2010), bahwa penentuan banyaknya sampel sesuai dengan banyaknya jumlah item pertanyaan (n) yang digunakan pada kuesioner tersebut, di mana dengan mengasumsikan rumus $\mathrm{n} \times 5$, sehingga dalam penelitian ini didapatkan 110 responden dengan jumlah pertanyaan dalam kuesioner sebanyak 22 pertanyaan.

Pada penelitian ini, digunakan skala Likert yang telah dimodifikasi menjadi empat angka penilaian dengan menghilangkan penilaian ragu-ragu atau netral. Hal ini dilakukan untuk mencegah responden yang netral atau tidak memilih., pencantuman pilihan netral seringkali tidak disukai mengingat responden yang tidak mau menentukan sikap akan menjatuhkan pilihannya pada jawaban netral atau ragu-ragu.

Untuk keperluan analisis kuantitatif, maka jawaban diberi skor, seperti :

1. Sangat setuju/Selalu/Sangat positif diberi skor $\quad 4$

2. Setuju/Sering/Positif diberi skor 3

3. Tidak Setuju/Hampir tidak pernah/Negatif diberi skor 2

4. Sangat tidak setuju/Tidak pernah/Sangat negatif diberi skor 1

\section{Hasil dan Pembahasan}

\subsection{Demografis Responden}

Dalam penelitian ini melibatkan 110 responden yang menjadi sampel, dimana responden ini diambil berdasarkan kriteria yang telah ditentukan adalah sebagai berikut:

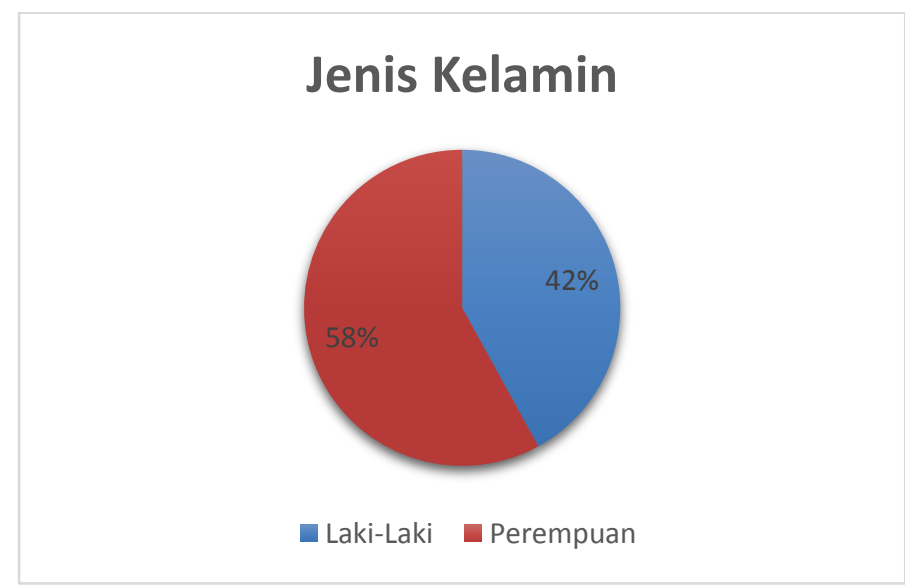

Gambar 3.1

Data Responden Berdasarkan Jenis Kelamin 
Berdasarkan hasil pengolahan data 110 responden berdasarkan jenis kelamin adalah laki-laki $42 \%$ dan Wanita $58 \%$. Hal ini dapat disimpulkan bahwa responden wanita menjadi mayoritas dalam pengisian kuesioner tersebut.

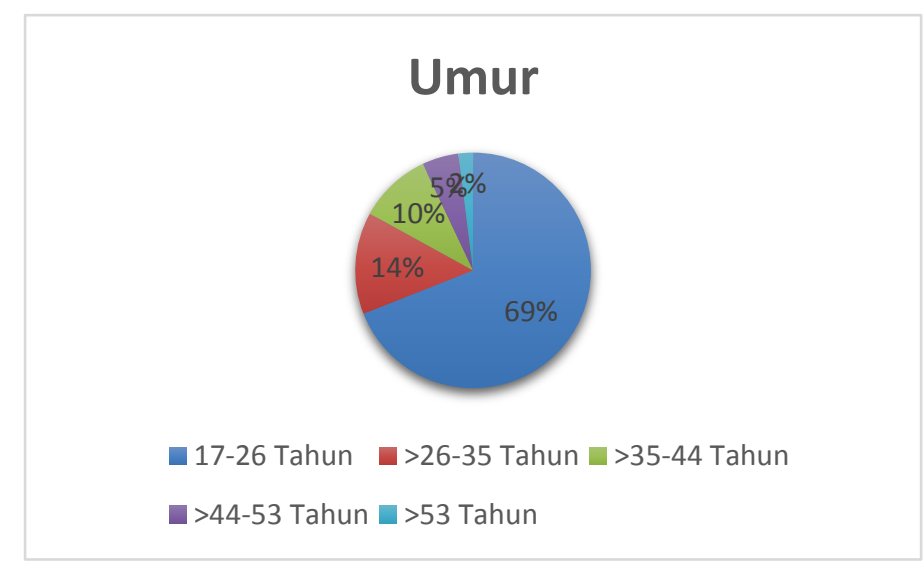

Gambar 3.2

Data Responden Berdasarkan Umur

Berdasarkan hasil penyebaran kuesioner sebanyak 110 responden berdasarkan umur terlihat bahwa umur responden 17-26 tahun sebanyak 69\%, sedangkan umur responden $>26-35$ tahun sebesar $14 \%$ dan umur responden >35-44 Tahun sebesar $10 \%$, umur responden $>53$ tahun sebesar $2 \%$. Hal ini dapat disimpulkan bahwa minat kunjungan wisatawan tertinggi pada umur 17-26 tahun.

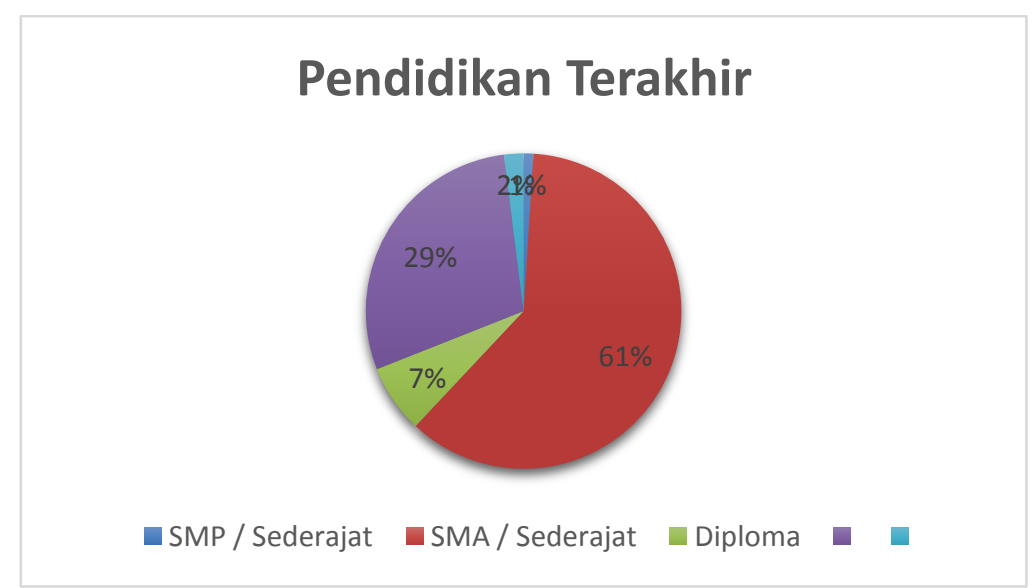

Gambar 3.3

Data Responden Berdasarkan Pendidikan Terakhir

Berdasarkan hasil responden sebanyak 110 Responden berdasarkan pendidikan terakhir $61 \%$ pada tingkat SMA/Sederajat. Sedangkan $29 \%$ pada tingkat S1 atau sarjana, 7\% responden pada tingkat diploma, $2 \%$ pada tingkat SMP Sederajat dan $1 \%$ Tidak tamat SD. Hal ini disimpulkan bahwa responden terbanyak pada tingkatan SMA/Sederajat. 


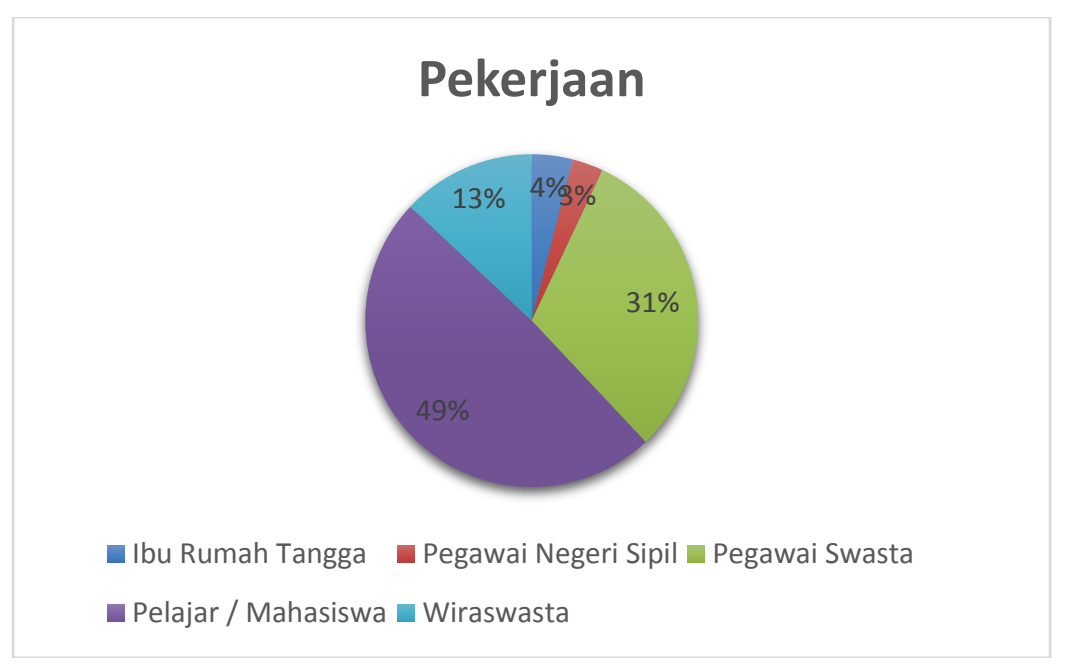

\section{Gambar 3.4 \\ Data Responden Berdasarkan Pekerjaan}

Berdasarkan data 110 responden didapatkan bahwa $49 \%$ pada tingkatan pekerjaan Pelajar/mahasiswa, 31\% pada tingkatan pegawai swasta, $13 \%$ terdapat pada tingkatan wiraswasta, 4\% pada tingkatan ibu rumah tangga, 3\% pada tingkatan pekerjaan Pegawai Negeri Sipil.

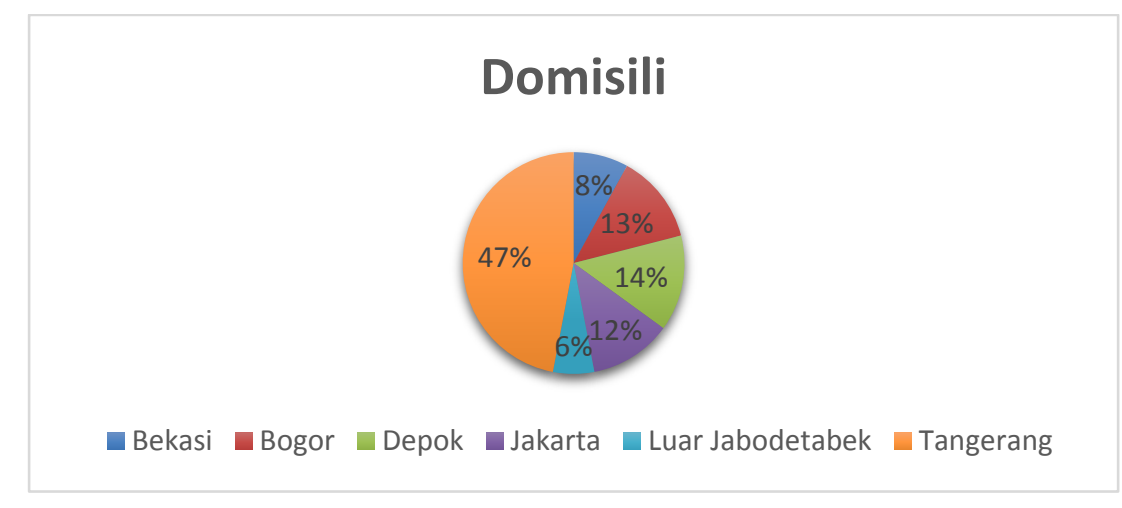

\section{Gambar 3.5 \\ Data Responden Berdasarkan Domisili}

Berdasarkan data 110 Responden didapatkan bahwa terdapat $47 \%$ berdomisili di Tangerang, $14 \%$ berdomisili di Depok, $13 \%$ berdomisili di Bogor, $12 \%$ berdomisili di Jakarta, $8 \%$ berdomisili di Bekasi dan $6 \%$ berdomisili di Luar jabodetabek. Hal ini dapat disimpulkan responden terbanyak berasal dari Tangerang.

Mayoritas responden berdomisili di Tangerang, merupakan wisatawan lokal atau yang disebut juga sebagai pelancong karena merupakan orang yang berkunjung sementara dan tinggal kurang dari 24 jam pada destinasi yang dikunjungi dan tidak bermalam. Mayoritas responden yang merupakan wisatawan lokal ini dikarenakan pada saat penyebaran kuesioner dilaksanakan pada bulan Mei 2020 saat sedang terjadi Pandemi Covid-19 dan adanya penerapan aturan PSBB (Pembatasan Sosial Berskala Besar) di Kota Tangerang yang dimulai pada tanggal 18 April 2020. Hal ini menyebabkan jumlah kunjungan wisatawan mancanegara sulit ditemui ketika penyebaran kuesioner dilakukan. Wisatawan yang berdomisili di Tangerang ini terdiri dari wisatawan yang berasal dari Tangerang Raya, termasuk Kabupaten Tangerang dan Kota Tangerang Selatan yang sedang berwisata ke Kota Tangerang. 


\subsection{Analisis Data dan Interpretasi}

\subsubsection{Uji Validitas}

Pada penelitian ini, sampel percobaan yang digunakan sebanyak 30 sampel dengan signifikansi $5 \%$, sehingga nilai $\mathrm{r}$ tabel yaitu 0,361 . Perhitungan ini akan dibantu pengolahannya dengan menggunakan program SPSS (Statistical Product and Service Solutions) versi 22. Untuk menentukan nomor item yang valid dan yang tidak valid perlu dikonfirmasi dengan menggunakan tabel r Product Moment. Jadi, dapat disimpulkan sebagai berikut:

Tabel 3.1

Uji Validitas Variabel X

\begin{tabular}{|c|c|c|c|c|}
\hline No & Variabel Pertanyaan & R - Hitung & R-Tabel & Keterangan \\
\hline 1 & Pertanyaan 1 & 0,701 & 0,361 & Valid \\
\hline 2 & Pertanyaan 2 & 0,756 & 0,361 & Valid \\
\hline 3 & Pertanyaan 3 & 0,827 & 0,361 & Valid \\
\hline 4 & Pertanyaan 4 & 0,896 & 0,361 & Valid \\
\hline 5 & Pertanyaan 5 & 0,826 & 0,361 & Valid \\
\hline 6 & Pertanyaan 6 & 0,883 & 0,361 & Valid \\
\hline 7 & Pertanyaan 7 & 0,857 & 0,361 & Valid \\
\hline 8 & Pertanyaan 8 & 0,687 & 0,361 & Valid \\
\hline 9 & Pertanyaan 9 & 0,830 & 0,361 & Valid \\
\hline 10 & Pertanyaan 10 & 0,737 & 0,361 & Valid \\
\hline 11 & Pertanyaan 11 & 0,828 & 0,361 & Valid \\
\hline 12 & Pertanyaan 12 & 0,747 & 0,361 & Valid \\
\hline 13 & Pertanyaan 13 & 0,753 & 0,361 & Valid \\
\hline 14 & Pertanyaan 14 & 0,423 & 0,361 & Valid \\
\hline 15 & Pertanyaan 15 & 0,780 & 0,361 & Valid \\
\hline 16 & Pertanyaan 16 & 0,885 & 0,361 & Valid \\
\hline 17 & Pertanyaan 17 & 0,863 & 0,361 & Valid \\
\hline 18 & Pertanyaan 18 & 0,798 & 0,361 & Valid \\
\hline 19 & Pertanyaan 19 & 0,747 & 0,361 & Valid \\
\hline 20 & Pertanyaan 20 & 0,829 & 0,361 & Valid \\
\hline 21 & Pertanyaan 21 & 0,813 & 0,361 & Valid \\
\hline 22 & Pertanyaan 22 & 0,808 & 0,361 & Valid \\
\hline
\end{tabular}


Berdasarkan hasil pengolahan data dengan SPSS Versi 22. 0, semua pertanyaan dimensi attraction, accessibilities, amenities dan ancillary service dinyatakan bersifat Valid.

Tabel 3.2

Uji Validitas Variabel Y

\begin{tabular}{lllll}
\hline No & Variabel Pertanyaan & R - Hitung & R- Tabel & Keterangan \\
\hline 1 & Pertanyaan 1 & 0,0626 & 0,361 & Valid
\end{tabular}

Sumber : Data diolah peneliti, 2020

Berdasarkan hasil pengolahan data dengan SPSS Versi 22. 0, variabel Y (Minat Kunjungan Wisatawan) dinyatakan bersifat Valid

\subsubsection{Uji Reliabilitas}

Berdasarkan hasil perhitungan Uji Reliabilitas dengan SPSS Versi 22. 0, maka suatu kuesioner dapat dikatakan reliable jika jawaban responden terhadap suatu pernyatan konsisten atau stabil dari waktu ke waktu.

Adapun hasil uji reliabilitas pada dimensi attraction dengan menggunakan SPSS Versi 22.0 ditemukan hasil sebagai berikut:

\section{Tabel 3.4}

Hasil Perhitungan Uji Reliabilitas Attraction Reliability Statistics

\begin{tabular}{|c|c|c|}
\hline $\begin{array}{l}\text { Cronbach' } \\
\text { s Alpha }\end{array}$ & $\begin{array}{c}\text { Cronbach' } \\
\text { s Alpha Based } \\
\text { on } \\
\text { Standardized } \\
\text { Items } \\
\end{array}$ & $\begin{array}{l}\mathrm{N} \text { of } \\
\text { Items }\end{array}$ \\
\hline .917 & .920 & 7 \\
\hline
\end{tabular}

Berdasarkan hasil pengujian reliabilitas pada tabel di atas, terlihat bahwa Cronbach Alpha pada dimensi atraction memiliki nilai 0,917. Sehingga dapat disimpulkan bahwa seluruh pernyataan pada dimensi tersebut memiliki tingkat interpretasi sangat tinggi dan dapat dilanjutkan ke tahapan berikutnya.

\section{Tabel 3.5}

\section{Hasil Perhitungan Uji Reliabilitas Accessibilities} Reliability Statistics

\begin{tabular}{|c|c|c|}
\hline $\begin{array}{l}\text { Cronbach' } \\
\text { s Alpha }\end{array}$ & $\begin{array}{l}\text { Cronbach' } \\
\text { s Alpha Based } \\
\text { on } \\
\text { Standardized } \\
\text { Items }\end{array}$ & $\begin{array}{l}\mathrm{N} \text { of } \\
\text { Items }\end{array}$ \\
\hline .822 & .843 & 7 \\
\hline
\end{tabular}

Berdasarkan hasil pengujian reliabilitas pada tabel di atas, terlihat bahwa Cronbach Alpha pada dimensi accessibilities memiliki nilai 0,822. Sehingga dapat disimpulkan bahwa seluruh pernyataan pada dimensi tersebut memiliki tingkat interpretasi sangat tinggi dan dapat dilanjutkan ke tahapan berikutnya. 


\section{Tabel 3.6}

Hasil Perhitungan Uji Reliabilitas Amenities Reliability Statistics

\begin{tabular}{|c|c|c|}
\hline $\begin{array}{l}\text { Cronbach' } \\
\text { s Alpha }\end{array}$ & $\begin{array}{c}\text { Cronbach' } \\
\text { s Alpha Based } \\
\text { on } \\
\text { Standardized } \\
\text { Items }\end{array}$ & $\begin{array}{c}\mathrm{N} \text { of } \\
\text { Items }\end{array}$ \\
\hline .838 & .853 & $\overline{4}$ \\
\hline
\end{tabular}

Berdasarkan hasil pengujian reliabilitas pada tabel di atas, terlihat bahwa Cronbach Alpha pada dimensi amenities memiliki nilai 0,838. Sehingga dapat disimpulkan bahwa seluruh pernyataan pada dimensi tersebut memiliki tingkat interpretasi sangat tinggi dan dapat dilanjutkan ke tahapan berikutnya.

Tabel 3.7

Hasil Perhitungan Uji Reliabilitas Ancillary Service Reliability Statistics

\begin{tabular}{|c|c|c|}
\hline $\begin{array}{l}\text { Cronbach' } \\
\text { s Alpha }\end{array}$ & $\begin{array}{l}\text { Cronbach' } \\
\text { s Alpha Based } \\
\text { on } \\
\text { Standardized } \\
\text { Items }\end{array}$ & $\begin{array}{l}\mathrm{N} \text { of } \\
\text { Items }\end{array}$ \\
\hline .792 & .816 & 4 \\
\hline
\end{tabular}

Berdasarkan hasil pengujian reliabilitas pada tabel di atas, terlihat bahwa Cronbach Alpha pada dimensi ancillary service memiliki nilai 0,792 . Sehingga dapat disimpulkan bahwa seluruh pernyataan pada dimensi tersebut memiliki tingkat interpretasi tinggi dan dapat dilanjutkan ke tahapan berikutnya.

Tabel 3.8

Hasil Perhitungan Uji Reliabilitas Y

Reliability Statistics

\begin{tabular}{|c|c|c|}
\hline $\begin{array}{l}\text { Cronbach' } \\
\text { s Alpha }\end{array}$ & $\begin{array}{l}\text { Cronbach' } \\
\text { s Alpha Based } \\
\text { on } \\
\text { Standardized } \\
\text { Items }\end{array}$ & $\begin{array}{l}\mathrm{N} \text { of } \\
\text { Items }\end{array}$ \\
\hline .077 & .754 & 2 \\
\hline
\end{tabular}

Berdasarkan hasil pengujian reliabilitas pada tabel di atas, terlihat bahwa Cronbach Alpha pada variabel Y (Minat Kunjungan Wisatawan) memiliki nilai 0,077. Sehingga dapat disimpulkan bahwa seluruh pernyataan pada varibel Y memiliki tingkat interpretasi sangat rendah dan dapat dilanjutkan 


\subsubsection{Uji T}

Hasil uji t dapat dilihat oleh tabel berikut ini:

Tabel 3.9 Hasil Uji t

Coefficients $^{\mathrm{a}}$

\begin{tabular}{|c|c|c|c|c|c|c|c|c|}
\hline \multirow[b]{2}{*}{ Model } & & \multicolumn{2}{|c|}{$\begin{array}{l}\text { Unstandardi } \\
\text { zed Coefficients }\end{array}$} & \multirow{2}{*}{$\begin{array}{c}\text { Standardi } \\
\text { zed } \\
\text { Coefficients } \\
\text { Beta } \\
\end{array}$} & \multirow[b]{2}{*}{$\mathrm{t}$} & \multirow[b]{2}{*}{$\begin{array}{l}\text { Si } \\
\text { g. }\end{array}$} & \multicolumn{2}{|c|}{$\begin{array}{l}\text { Collinearity } \\
\text { Statistics }\end{array}$} \\
\hline & & $\mathrm{B}$ & $\begin{array}{r}\text { St } \\
\text { d. Error } \\
\end{array}$ & & & & $\begin{array}{c}\text { Tolera } \\
\text { nce }\end{array}$ & $\mathrm{F}^{\mathrm{VI}}$ \\
\hline 1 & (Consta & $\begin{array}{r}- \\
.761\end{array}$ & $\begin{array}{r}.2 \\
21\end{array}$ & & $3.444^{-}$ & $\begin{array}{r}.0 \\
01\end{array}$ & & \\
\hline & ATT & $\begin{array}{r}.0 \\
34\end{array}$ & $\begin{array}{r}.0 \\
15\end{array}$ & .320 & $\begin{array}{r}2.2 \\
65 \\
\end{array}$ & $\begin{array}{r}.0 \\
26\end{array}$ & .323 & $\begin{array}{r}3.0 \\
95\end{array}$ \\
\hline & $\mathrm{ACC}$ & $\begin{array}{l}.0 \\
17\end{array}$ & $\begin{array}{r}.0 \\
16\end{array}$ & .142 & $\begin{array}{l}1.1 \\
21\end{array}$ & $\begin{array}{r}.2 \\
65 \\
\end{array}$ & .404 & $\begin{array}{r}2.4 \\
75 \\
\end{array}$ \\
\hline & $\mathrm{AM}$ & $\begin{array}{r}.0 \\
27\end{array}$ & $\begin{array}{r}.0 \\
22 \\
\end{array}$ & .153 & $\begin{array}{r}1.2 \\
16 \\
\end{array}$ & $\begin{array}{r}.2 \\
27 \\
\end{array}$ & .408 & $\begin{array}{r}2.4 \\
53 \\
\end{array}$ \\
\hline & ANC & $\begin{array}{r}.0 \\
16 \\
\end{array}$ & $\begin{array}{r}.0 \\
26 \\
\end{array}$ & .084 & $\begin{array}{r}.63 \\
2\end{array}$ & $\begin{array}{r}.5 \\
29\end{array}$ & .370 & $\begin{array}{r}2.7 \\
01\end{array}$ \\
\hline
\end{tabular}

a. Dependent Variabel: Y

Sumber: Data diolah peneliti, 2020

Penjelasan hasil uji t sebagai berikut:

1. Dimensi attraction memiliki signifikansi $0,026<0,05$, yang berarti bahwa Ho ditolak dan Ha diterima yang berarti bahwa dimensi attraction berpengaruh secara signifikan terhadap variabel terikat. Sedangkan pada perhitungan perbandingan $t$ hitung dan $t-$ tabel didapat bahwa $2.265>\mathrm{t}$ - tabel bahwa Ho ditolak dan Ha diterima yang berarti dimensi attraction berpengaruh secara signifikan terhadap variabel terikat.

2. Dimensi accessibilities memiliki signifikansi 0,265 >0,05, yang berarti bahwa Ho diterima dan Ha ditolak yang berarti bahwa dimensi accessibilities tidak berpengaruh secara signifikan terhadap variabel terikat. Sedangkan pada perhitungan perbandingan $t$ hitung dan $\mathrm{t}$ - tabel didapat bahwa $1.121<\mathrm{t}$ - tabel bahwa Ho diterima dan Ha ditolak yang berarti dimensi accessibilities tidak berpengaruh secara signifikan terhadap variabel terikat.

3. Dimensi amenities memiliki signifikasi 0,227 >0,05, yang berarti bahwa Ho diterima dan Ha ditolak yang berarti bahwa dimensi amenities tidak berpengaruh secara signifikan terhadap variabel terikat. Sedangkan pada perhitungan perbandingan t hitung dan $t-$ tabel didapat bahwa $1.216<\mathrm{t}$ - tabel bahwa Ho diterima dan Ha ditolak yang berarti imensi amenities tidak berpengaruh secara signifikan terhadap variabel terikat.

4. Dimensi ancillary service memiliki signifikasi $0,529>0,05$, yang berarti bahwa Ho diterima dan Ha ditolak yang berarti bahwa dimensi ancillary service tidak berpengaruh secara signifikan terhadap variabel terikat. Sedangkan pada perhitungan perbandingan $t$ hitung dan $\mathrm{t}$ - tabel didapat bahwa $0.632<\mathrm{t}$ - tabel bahwa Ho diterima dan Ha ditolak yang berarti imensi ancillary service tidak berpengaruh secara signifikan terhadap variabel terikat. 


\subsubsection{Uji F}

Menurut Ghozali (2013), uji statistik F bertujuan untuk menunjukkan apakah semua variabel independen yang dimasukkan ke dalam model mempunyai pengaruh terhadap variabel dependen.

Tabel 3.10 Hasil Uji F

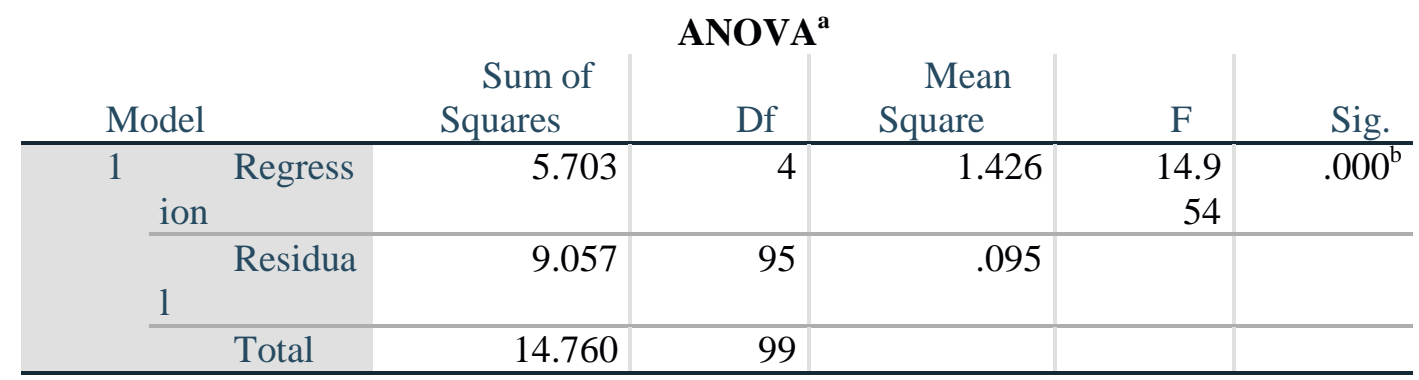

a. Dependent Variabel: Y

b. Predictors: (Constant), ANC, AM, ACC, ATT

Sumber : Data diolah peneliti, 2020

Jika dilihat dari tabel ANOVA, terlihat bahwa signifikansi $0,000<0,05$. Oleh karena itu dapat disimpulkan bahwa Ho ditolak dan Ha diterima. Artinya semua dimensi pada komponen destinasi wisata secara silmutan (bersama-sama) berpengaruh signifikan terhadap variabel Y (Minat kunjungan wisatawan) dan hasil F-hitung $>2.70$ yang berarti bahwa secara simultan (bersamasama) berpengaruh terhadap variabel Y (Minat Kunjungan Wisatawan).

\subsubsection{Koefisien Determinasi $\left(\mathbf{R}^{2}\right)$}

Ghozali (2013) menyatakan bahwa analisis koefisien determinasi bertujuan untuk mengukur seberapa jauh kemampuan model dalam menerangkan variasi variabel dependen.

\section{Tabel 3.11 Koefisien Determinasi $\left(\mathbf{R}^{2}\right)$}

\begin{tabular}{rc|c|c|r|r}
\multicolumn{1}{c}{ M } & \multicolumn{4}{|c}{ Model Summary $^{\mathbf{b}}$} \\
odel & $\mathrm{R}$ & Square & $\begin{array}{c}\text { Adjusted } \\
\text { R Square }\end{array}$ & $\begin{array}{r}\text { Std. Error } \\
\text { of the Estimate }\end{array}$ & $\begin{array}{c}\text { Durbin- } \\
\text { Watson }\end{array}$ \\
\hline 1 & $.622^{\mathrm{a}}$ & .386 & .361 & .30877 & 1.714 \\
\hline
\end{tabular}

a. Predictors: (Constant), ANC, AM, ACC, ATT

b. Dependent Variabel: Y

Sumber : Data diolah peneliti, 2020

Nilai koefisien determinasi yaitu berkisar antara nol sampai satu. Nilai koefisien determinasi $\left(\mathrm{R}^{2}\right)$ yang kecil, atau mendekati nol, diartikan bahwa kemampuan variabel-variabel independen dalam menjelaskan variasi variabel dependen amat terbatas. Sebaliknya, jika nilai koefisien determinasi $\left(\mathrm{R}^{2}\right)$ besar, atau mendekati satu, diartikan bahwa variabel-variabel independen memberikan hampir seluruh informasi yang dibutuhkan untuk memprediksi variasi variabel dependen. Berdasarkan uji Koefisien Determinasi terlihat hasil dari perhitungan tabel diatas adalah sebesar 0,386 atau $38,6 \%$ sisanya $62,4 \%$ dipengaruhi oleh variabel lain yang tidak diteliti dalam penelitian ini. 


\section{Kesimpulan dan Saran}

\subsection{Kesimpulan}

Berdasarkan hasil analisa dan pembahasan pada bab sebelumnya melalui proses pengujian dengan menggunakan SPSS Versi 22.0 maka dapat diambil kesimpulan sebagai berikut:

- Berdasarkan karakteristik responden yang diteliti, mayoritas responden berjenis kelamin Wanita yaitu sebesar $58 \%$, sedangkan berdasarkan umur, mayoritas responden berumur 1726 tahun yaitu sebesar $69 \%$, pendidikan terakhir mayoritas responden yaitu pada tingkat SMA/Sederajat sebesar $61 \%$, mayoritas responden merupakan Pelajar/Mahasiswa yaitu sebesar $49 \%$, dan sebesar $47 \%$ responden berdomisili di Tangerang.

- Berdasarkan hasil perhitungan Uji t secara partial didapatkan dimensi attraction memiliki pengaruh yang signifikan terhadap minat kunjungan wisatawan. Sedangkan dimensi accessibilities, amenities dan ancillary service tidak mempunyai pengaruh signifikan terhadap Y (Minat Berkunjung Wisatawan) karena signifikansi $>0.05$ dan perbandingan thitung < t-tabel.

- Berdasarkan hasil perhitungan Uji F secara simultan didapatkan mempunyai pengaruh signifikan terhadap minat kunjungan wisatawan karena signifikansi $<0.05$ dan Hasil FHitung $>2.70$ yang berarti secara simultan mempunyai pengaruh signifikan terhadap $\mathrm{Y}$ (Minat Kunjungan Wisatawan)

- Berdasarkan hasil Uji Koefisien Determinasi didapatkan sebesar 0,386 atau 38,6 \% sisanya $62,4 \%$ dipengaruhi oleh variabel lain yang tidak diteliti dalam penelitian ini.

\subsection{Saran}

Berdasarkan hasil penelitian yang telah dilakukan, berikut merupakan saran yang ditujukan bagi penelitian selanjutnya adalah:

- Pada dimensi attraction peneliti memberikan saran dan masukan agar dapat lebih dikembangkan dan dibuat lebih menarik serta mempunyai keunikan atau ciri khas, seperti memperbanyak penjual makanan khas Kota Tangerang, sehingga membuat wisatawan lebih tertarik untuk datang.

- Pada dimensi accessibilities peneliti memberikan saran dan masukan agar memberikan informasi detail mengenai akses menuju tempat lokasi, diberikan tanda atau petunjuk jalan disekitar tempat menuju akses lokasi penelitian.

- Pada dimensi amenities peneliti memberikan saran dan masukan melengkapi fasilitas umum dan menyediakan fasilitas sesuai dengan kebutuhan wisatawan, seperti toilet umum dan tempat mencuci tangan, serta menjaga kebersihan fasilitas umum.

- Pada dimensi ancillary service peneliti memberikan saran dan masukan melengkapi layanan tambahan seperti pos keamanan agar wisatawan merasa lebih aman serta layanan tambahan lain seperti Anjungan Tunai Mandiri (ATM) dan Fasilitas penukaran mata uang (Money Changer).

- Diperlukan penelitian selanjutnya mengenai pemasaran atau pengembangan wisata kuliner yang tidak diteliti dalam penelitian ini. 


\section{Referensi}

Arikunto, S. (2013). Prosedur Penelitian: Suatu Pendekatan Praktik. Jakarta: Rineka Cipta.

Ghozali, I. (2013). Aplikasi Analisis Multivariate dengan Program SPSS. Edisi Ketujuh. Semarang: Universitas Diponegoro.

Hair, Jr et.al. (2010). Multivariate Data Analysis (7th ed). United States: Pearson.

\section{Jurnal:}

Kristiana, Yustisia., Suryadi, M. T., \& Sunarya, S. R. (2018). Eksplorasi Potensi Wisata Kuliner Untuk Pengembangan Pariwisata Di Kota Tangerang. Jurnal Khasanah Ilmu Vol. 9 No. 1.

Anggela, M. M., Karini, N. M., \& Wijaya, N. M. (2017). Persepsi Dan Motivasi Wisatawan Yang Berkunjung Ke Daya Tarik Wisata Jembong Di Kabupaten Buleleng. Jurnal IPTA, Vol. 5(No. 2).

Muliani, L. (2019). Potensi Bubur Ase Sebagai Daya Tarik Wisata Kuliner Jakarta. Destinesia Jurnal Hospitaliti \& Pariwisata, Vol. 1, No. 1.

Nengsih, M., \& Ariska, Y. (2020). Analisis Cluster Pengunjung Tempat Wisata (Studi Kasus: Pantai Panjang Bengkulu). EKOMBIS REVIEW: Jurnal Ilmiah Ekonomi Dan Bisnis, 8(1), 18.

Wilopo, N. R., \& Pangestuti, E. (2017). Pengaruh Efektivitas Iklan Online Terhadap Minat Berkunjung Serta Dampaknya Pada Keputusan Berkunjung Wisatawan Mancanegara ke DKI Jakarta. Jurnal Administrasi Bisnis.

Putra, D. A., \& Pangestuti, E. (2018). Pengaruh City Branding "The Heart Of East Java" Pada Minat Berkunjung dan Keputusan Berkunjung (Survei Pada Wisatawan Yang Berkunjung Ke Kabupaten Malang). Jurnal Administrasi Bisnis.

\section{Website:}

https://tangerangkota.bps.go.id/pencarian.html?searching=JUMLAH+WISATAWAN+NUSANTA RA+DAN+WISATAWAN+MANCANEGARA+DI+KOTA+TANGERANG\&yt1=Cari diakses pada tanggal 07 April 2020 